\title{
HISTOLOGICAL STUDY OF THE EFFECT OF BACTERIAL LYSATES ON THE STATE OF PERIODONTAL TISSUE IN EXPERIMENTAL PERIODONTITIS IN RATS
}

\author{
Mariia Ievtushenko, Olena Koshova, Svitlana Kryzhna
}

\begin{abstract}
The aim of the research: to experimentally study at the histological and morphological level the degree of the corrective effect of bacterial lysate of the disturbed non-specific defense of the body on the model of periodontitis based on the Central Research Laboratory of the National University of Pharmacy.

Materials and methods: prospective study has been conducted on experimental periodontitis in 42 rats for 90 days. The animals were treated with "Respibron» and the reference drug "Imudon». Histological and morphometric studies were carried out according to standard methods. Micropreparations were viewed under a Granum DCM 310 digital video camera. All interventions and euthanasia of animals were carried out in compliance with the European principles.

Results: by the end of 90 days of experimental periodontitis at the local level in the homogenate of animal gum tissue compensatory mechanisms are depleted and differed from the norm by 397 times. The dynamics of the studied morphometric and histological parameters of "Respibron" was similar to the "Imudon", but the magnitude of destruction was less pronounced and differed at the end of the experiment by 17.2 times in comparison with the intact control, and in the control group the results improved by 23.1 times.

Conclusion: the obtained data from the study indicate a high decompensation of experimental periodontitis. It is characterized by the formation of periodontal pockets and inflammatory bone loss. The magnitude of destruction differed from the norm by 397 times. Applying of bacterial lysates led to the compensation of bacterial dysbiosis, restoration of the tissues of paradont. The therapeutic effect of "Respibron" can be assessed as more powerful in comparison with "Imudon" in terms of the studied morphometric and histological parameters: the magnitude of improvement "Respibron" was 3.72 times higher than the indicators of "Imudon". We should continue the study of experimental periodontitis as mechanisms of development, protection, and restoration of tissues under conditions of pharmacological correction by bacterial lysate "Respibron"
\end{abstract}

Keywords: periodontitis, histological and morphometric profile, bacterial lysate

\section{How to cite:}

Ievtushenko, M., Koshova, O., Kryzhna, S. (2021). Histological study of the effect of bacterial lysates on the state of periodontal tissue in experimental periodontitis in rats. ScienceRise: Medical Science, 5 (44), 41-47. doi: http://doi.org/10.15587/2519-4798.2021.241983

(C) The Author(s) 2021

This is an open access article under the Creative Commons CC BY license hydrate

\section{Introduction}

The development of medicine has led to the understanding that almost any pathology is the cause or consequence of immunological disorders that contribute to the chronicity of the underlying disease and the occurrence of its complications [1]. The study of the issue of disturbance of the oral microbiota in inflammatory periodontal diseases made it possible to supplement the pathogenetic mechanisms of the formation of persistent pathomorphological changes in this pathology. Thus, it was found that inflammatory periodontal disease (IPD) are accompanied by immunological disorders of a general (systemic) and local levels, therefore, therapy is based on the establishment of an accurate clinical and immunological diagnosis and the appointment of appropriate immunocorrective therapy [2,3]. This tactic is pathogenetically justified and contributes to the achievement of positive clinical results and prolongation of remission. At the same time, the possibility of local immunodeficiency in the oral cavity and in the periodontium (based on the provision on the relative autonomy of the immune system) prompts a number of authors to develop mainly local methods for its correction [4]. One of the possible correction methods is the use of immunomodulators. Considering the presence of bacterial allergy in patients with IPD, the use of immunomodulators of bacterial origin is a reasonable approach to antiinfectious immunocorrection. Similar drugs ("Ribomunil", "Imudon" (France), etc.) provide fast nonspecific protection against viruses, bacteria, ribs and long-term specific protection against the main pathogens in IPD [5, 6]. Such agents are a lyophilized lysate of certain groups of bacteria most commonly found in dental plaque. Other similar preparations of the modern method of obtaining are distinguished by smaller antigenic molecules, with reduced ballast (antigen inactive), toxic parts of the microbial cell as "Respibron". Accordingly, this antigenic material is better recognized by the immune system and, therefore, forms a specific immune response, and the absence of toxic components makes it possible to avoid a general negative reaction of the body [7]. At this stage of our study, the task was to establish the dynamics of mor- 
phological disorders, and a comparative analysis of the effectiveness of the use of "Respibron" in the treatment of experimental periodontitis in rats.

The aim of the work was experimentally study at the histological and morphological level the degree of the corrective effect of bacterial lysate of the disturbed nonspecific defense of the body at the local level on the model of periodontitis based on the Central Research Laboratory of the National University of Pharmacy.

\section{Materials and methods}

The studies were carried out at the Central Scientific Research Laboratory of the NUPh, which is certified by the State Pharmacological Center of the Ministry of Health of Ukraine (certificate No. 008/11 dated 18.10.2011). Experiments were carried out in the fall of 2020 on 48 outbred

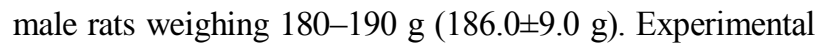
periodontitis in rats was caused by keeping rats on a light consistency diet with a high carbohydrate content for O. I. Evdokimov modified by A. Sukmansky and A. Makarenko [8]. There were no statistically significant differences in body weight in different groups. The animals were divided into 4 groups: 1st group - intact animals; 2nd group - rats with experimental periodontitis; 3rd - rats with experimental periodontitis, which were irrigated with an aqueous solution of «Respibron» at a dose of $10 \mathrm{mg} / \mathrm{kg}$ once a day; 4th group - rats with experimental periodontitis, which were irrigated with an aqueous solution of the reference drug. The duration of the experiment was 90 days: the simulation of periodontitis lasted 60 days (30 days were treated with «Respibron» (bacterial lysate) and the reference drug - a well-known agent with immunomodulatory properties «Imudon», which includes lysates of strains of the most common bacterial pathogens of the pathological process in the cavity mouth) [9]. Its mechanism of action is to stimulate the protective reactions of the oral mucosa by increasing the phagocytic activity of polymorphonuclear leukocytes (PML), the content of lysozyme in mixed saliva, stimulation of immunocompetent cells, as well as stimulation and increase of secretory IgA.

All animal studies were performed in accordance with Directive 2010/63/EU as amended by Regulation (EC) 2019/1010 and approved by conclusion of the Commission on Ethics and Bioethics of the National University Pharmacy (protocol No. 1 dated 02/05/2020).

All interventions and euthanasia of animals were carried out in compliance with the principles of the "European Convention for the Protection of Vertebrate Animals used for Experimental and Other Scientific Purposes" (Strasbourg, 1986, as amended in 1998) and the resolution of the Fifth National Congress on Bioethics (Kiev, 2013).

Fragments of periodontal tissues of rats of 4 groups became the material for histological examination. The therapeutic fusion of the oral cavity lasted 30 days. The rats of the studied groups were withdrawn from the experiment on day 90 after the start of the experiment. In accordance with the provisions of the European Convention for the Protection of the Rights of Vertebrate Animals Used for Research and Other Scientific Purposes, the withdrawal of animals from the experiment was carried out by decapitation under light chloroform anesthesia.

Pieces of the jaw with teeth and gums were fixed in $10 \%$ formalin solution, decalcified in $5 \%$ nitric acid solution (control of the exposure time of the samples in the decalcifying liquid was carried out by piercing the bone with a dissecting needle), dehydrated with alcohols of increasing strength, and embedded in paraffin. Using a sled microtome, sections with a thickness of $6-8 \mu \mathrm{m}$ were made from paraffin blocks, shaped on a glass slide, and stained with hematoxylin and eosin [9]. To objectify the results of survey microscopy on photographs using the Toupcam Granum software, morphometric measurements were carried out - the distance from: the bifurcation point to the crest of the interroot septum was determined; the level of epithelial attachment to the upper edge of the gingival papilla - the height of the gingival papilla; the level of the enamel-cement border to the interalveolar septum; enamel-cement border to the bottom of the tooth-gingival pocket - the magnitude of destruction. Micropreparations were viewed under a Granum light microscope, microscopic images were taken with a Granum DCM 310 digital video camera. The photographs were processed on a Pentium $2.4 \mathrm{GHz}$ computer using the ToupView software. Statistical data processing was performed using the STATISTICA for WINDOWS 6.0 software package. Quantitative indicators in the table are given as the arithmetic mean and its standard error $(\mathrm{M} \pm \mathrm{m})$. The indicator "From the enamel-cement boundary to the bottom of the tooth-ash claw (destruction value)" is given as the minimum and maximum values of the sample $\mathrm{M}(\min ; \max )$ and the median, lower and upper quartels (Me (Q25; Q75). Checking the normal distribution quantitative data were performed using the Shapiro-Wilk test and the Leuven test. If the obtained data corresponded to a normal distribution, ANOVA was used, and intergroup comparisons of indicators were performed using the Newman-Keuls test and the KruskalWallis test. Paired intergroup comparisons of indicators were carried out according to the Mann-Whitney U test The critical value of the significance level was taken to be less than $0.05(p<0.05),[8,9])$. Evaluation of the results of biochemical studies was carried out in accordance with existing standards by comparing the indicators of the comparison group with the main and initial indicators, as well as between the subgroups of the comparison group, depending on the exposure of the experiment [8].

\section{Research results}

Reproduction of experimental periodontitis according to the above method, as shown by the results obtained, significantly led to non-specific structural changes of different expressiveness in both soft and hard periodontal tissues. In the group of control pathology, signs of resorption are visible in the bones - serration of the lateral edges, the appearance of depressions, which were replaced by connective tissue, grew, and lymphocytes were rich. The periodontal ligament expanded unevenly, it revealed foci of destruction, focal leukocyte infiltration (Fig. 1). Whereas in the group of intact control on the microslides, the roots of the teeth, immersed in the alveolar bone of the process, are clearly visible, they are attached with the help of the periodontal ligament. The connective tissue fibers of the periodontal ligament are clearly oriented, tightly fused with the cement of the root. Cellular elements are few in number and are represented mainly by cells of the fibroblastic series, vessels without features. The surface of the alveolar bone is smooth. 
At the edge of the dental alveolus, the periodontal ligament passes into the gums. The gingival margin is tightly connected to the periosteum at the level of the enamel-cement border. Between the teeth, the gum forms the so-called interdental papilla. The depth of the gingival pocket coincides with the height of the gingival papilla. Interdental gingival papillae are covered with a thin layer of squamous keratinized epithelium (no more than $4-5$ rows of cells). The free gum is located along the periphery of the tooth. The mucous membrane of the free gum is lined with stratified squamous keratinizing epithelium. The border between the epithelium and the connective tissue is generally smooth. The vessels of the microvasculature of the lamina propria of the gingival mucosa are moderately full-blooded. Cellular infiltration of the lamina propria is small, represented mainly by lymphocytes (Fig. 2).

In the group with control pathology, the appearance of pathological tooth-gingival pockets was noted. The cavity of the pocket is filled with leukocytes and structureless basophilic masses, often the level of epithelial attachment did not coincide with the level of the enamel-cement border. Some interdental papillae were characterized by an ulcerative defect of the apex, in some cases the entire papilla was in a state of necrosis. In the tissues of the free gum, subepithelial leukocyte infiltrates of various expressiveness are visible (Fig. 3).

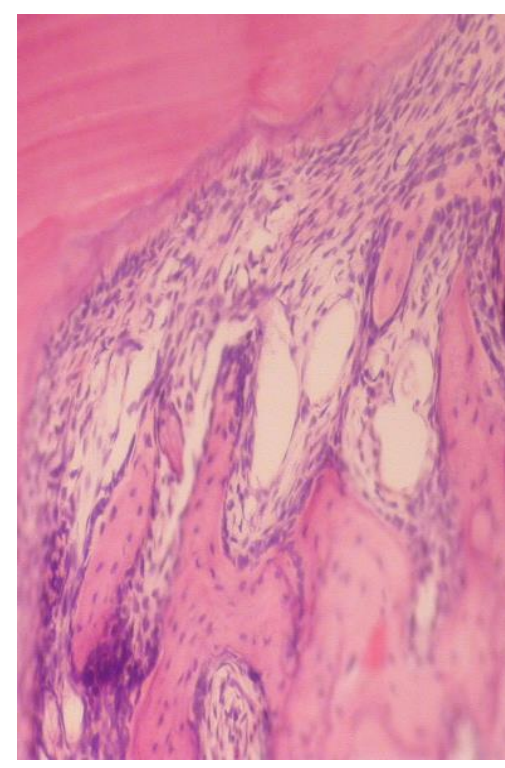

$a$

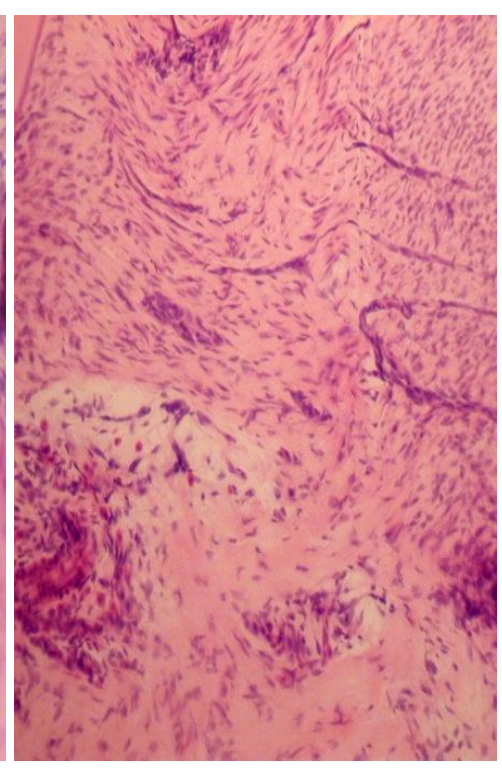

6

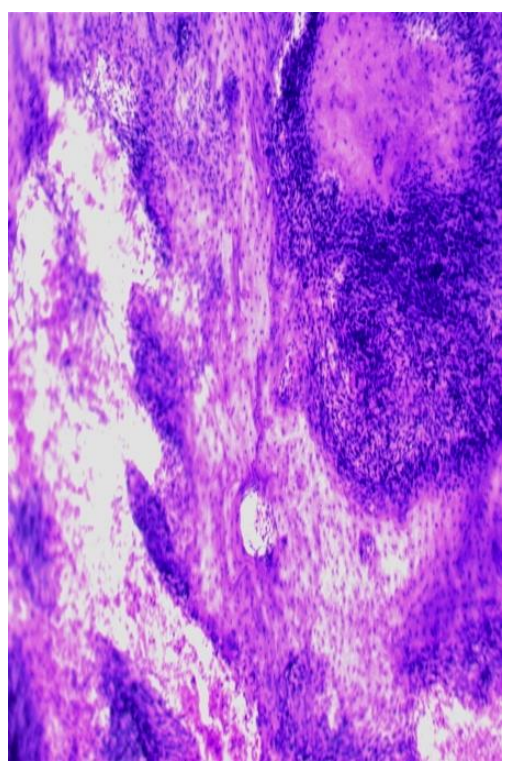

$c$

Fig. 1. Periodontal rat with experimental periodontitis: $a$ - resorption of the alveolar bone, the appearance of depressions, which were replaced by connective tissue; $b$ - significant expansion of the periodontal ligament; $c$-destruction, leukocyte infiltration of periodontal ligaments. Hematoxylin and eosin. $\times 200$

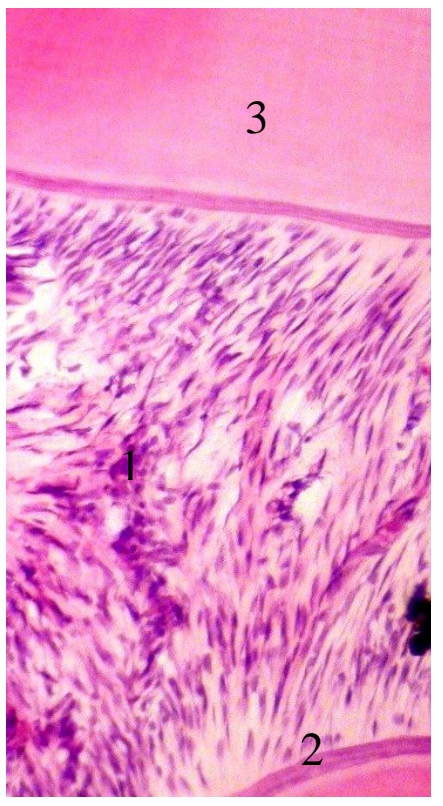

$a$

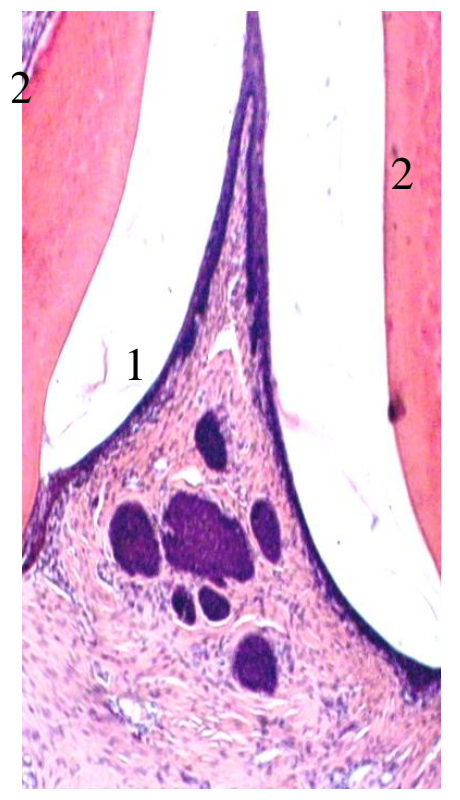

$\sigma$

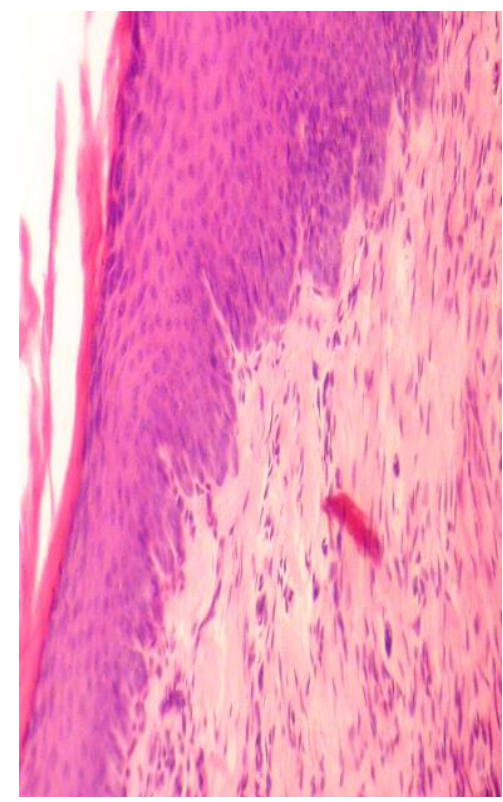

$c$

Fig. 2. Periodontium (a-b) and free gums (c) of an intact rat: $a$ - periodontal ligament (1) between the alveolar bone (2) and the tooth (3) without changes; $b$-gingival papilla (1) between the teeth (2) without signs of inflammation, covered with stratified squamous non-keratinizing epithelium; $c$ - normal mucous membrane of the gums. Hematoxylin and eosin. a, $\mathrm{c}-\times 250, \mathrm{~b}-\times 100$ 


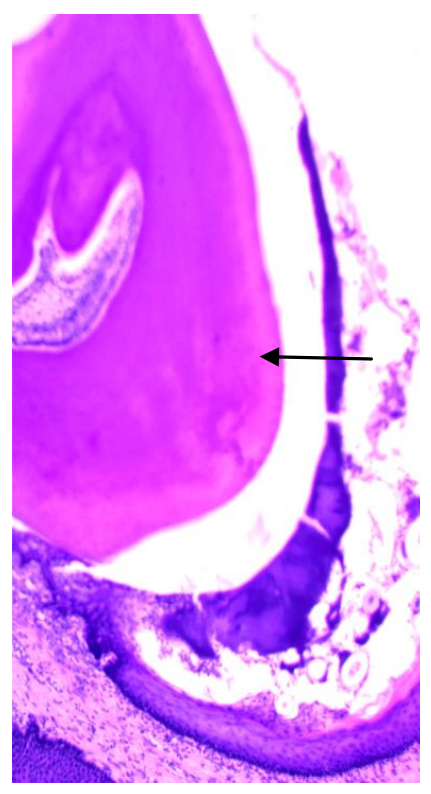

$a$

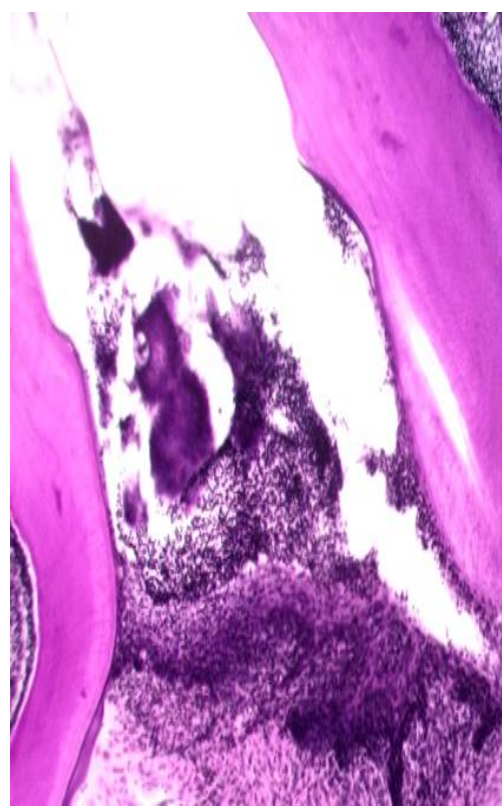

$b$

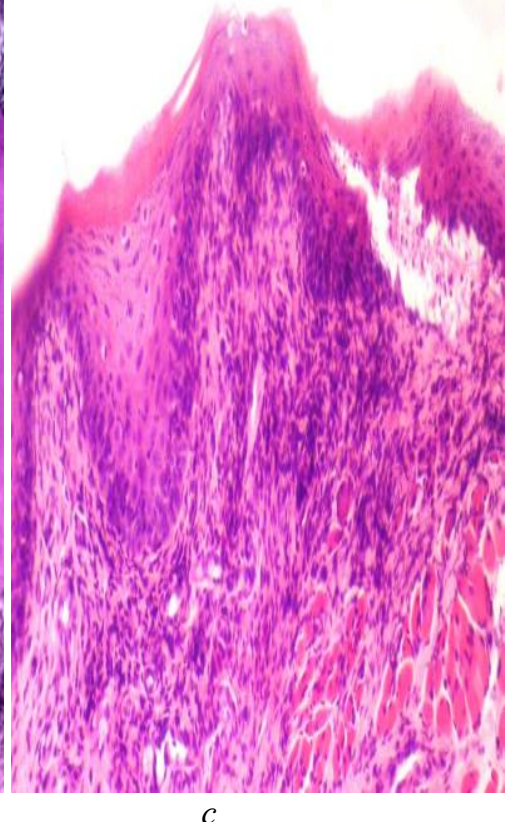

$c$

Fig. 3. Periodontium (a, b) and free gums (c) of a rat with experimental periodontitis: $a$ - the dentogingival pocket is filled with basophilic masses (arrow), the epithelial layer of the bottom of the pocket is attached significantly below the level of the enamel-cement border; $b$ - necrosis of the interdental papilla; $c$ - leukocyte infiltration of subepithelial tissues of the free gums. Hematoxylin and eosin. $\times 100$

According to the results of morphometry in the intact control group, the distance from the enamel-cement border to the interalveolar septum is $453 \mu \mathrm{m}$. The interroot septum (its crest) to the bifurcation point is located at the level of 81.8 microns. The height of the gingival papillae is $427.4 \mu \mathrm{m}$. The magnitude of destruction is zero, since the gingival margin is connected to the periosteum clearly at the level of the enamel-cement border the depth of the tooth-gingival pocket coincides with the height of the gingival papilla (Table 1). Morphometric parameters in the group with control pathology confirm the microscopy data. The distance from the bifurcation point to the crest of the interradicular septum increased 1.92 times. The distance from the enamel-cement level to the bottom of the periodontal pocket was $397 \mu \mathrm{m}$, the height of the gingival papilla increased by $20.38 \%$, the distance from the enamel-cement border to the interalveolar septum - by $11.76 \%$.

Table 1

The comparative assessment of «Respibron» on the morphometric parameters of the periodontal tissues of rats with experimental periodontitis in comparison with «Imudon», at 90 days of experiment $(\mathrm{M} \pm \mathrm{m})$

\begin{tabular}{|c|c|c|c|c|}
\hline \multirow[b]{2}{*}{ Indicators, microns } & \multicolumn{4}{|c|}{$\begin{array}{r}\text { Animal groups } \\
\end{array}$} \\
\hline & $\begin{array}{l}\text { Intact control } \\
\qquad \mathrm{n}=12\end{array}$ & $\begin{array}{l}\text { Control pathol- } \\
\text { ogy (periodonti- } \\
\text { tis) } n=12\end{array}$ & $\begin{array}{l}\text { «Respibron» }+ \text { per- } \\
\text { iodontitis } n=12\end{array}$ & $\begin{array}{c}\text { «Imudon» + perio- } \\
\text { dontitis } n=12\end{array}$ \\
\hline Height of the gingival papilla & $427.4 \pm 3.97$ & $536.8 \pm 4.75^{*}$ & $432 \pm 2.54^{\S}$ & $470.6 \pm 9.72 *{ }^{8} \#$ \\
\hline $\begin{array}{l}\text { The distance from the bifurca- } \\
\text { tion point to the crest of the in- } \\
\text { terradicular septum }\end{array}$ & $81.8 \pm 1.07$ & $157.0 \pm 4.00^{*}$ & $87.2 \pm 1.16^{\S}$ & $108.2 \pm 7.09 *{ }^{\S} \#$ \\
\hline $\begin{array}{l}\text { The distance from the enamel- } \\
\text { cement boundary to the in- } \\
\text { teralveolar septum }\end{array}$ & $453 \pm 13.20$ & $513.4 \pm 4.20^{*}$ & $472.6 \pm 5.60^{\S}$ & $494.8 \pm 3.90 *$ \\
\hline \multirow{4}{*}{$\begin{array}{l}\text { Distance from the enamel- } \\
\text { cement border to the bottom of } \\
\text { the gingival pockets (the amount } \\
\text { of destruction) }\end{array}$} & \multicolumn{4}{|c|}{$\mathrm{M}(\min ; \max )$} \\
\hline & $0(0 ; 0)$ & $397(388 ; 405)^{*}$ & $17.2(0 ; 86)^{\S}$ & $64(0 ; 120)^{\S}$ \\
\hline & \multicolumn{4}{|c|}{$\mathrm{Me}(\mathrm{Q} 25 ; \mathrm{Q} 75)$} \\
\hline & $0(0 ; 0)$ & $\begin{array}{c}399 \\
(393 ; 400) *\end{array}$ & $0(0 ; 0)^{\S}$ & $\begin{array}{c}99 \\
(0 ; 101)^{\S}\end{array}$ \\
\hline
\end{tabular}

Note: $*-p<0.05$ the differences are statistically significant to the indices of intact control; ${ }^{\xi}-p<0.05$ the differences are statistically significant to the indicators of control pathology; \#-p<0.05; differences are statistically significant to the indicators of the "Imudon» group

After therapeutic irrigation of the mouth cavity "Respibron", in contrast to the control pathology, microscopically no signs of resorption of alveolar bones were found in rats, the periodontal ligament was not changed, the ratio between cellular and fiber elements in it was normal. Tooth-gingival pockets in depth practically coin- 
cide with the height of the gingival papilla, the level of epithelial attachment and the enamel-cement border coincide. The interdental gingival papillae themselves were preserved, only a slight thickening of the integumentary epithelium was visible. The epithelium of the free gums without signs of dystrophy, the subepithelial tissues are not changed, and the blood filling of the vessels of the microvasculature of the lamina propria of the mucous membrane corresponds to the intact control (Fig. 4). The data of morphometric measurements also indicate a significant improvement in the histological state of the peri- odontal tissues and are close to those in the intact control (Table 1).

In the vast majority of rats, which oral fusion was performed with the comparison drug "Imudon", there were no pathological changes in both hard and soft periodontal tissues (Fig. 5). Only one rat showed destructive changes in the periodontal ligament and some interdental papillae after therapeutic irrigation of the oral cavity "Imudon": destruction of the apex of the interdental gingival papilla, destruction and inflammatory infiltration of the periodontal ligament.
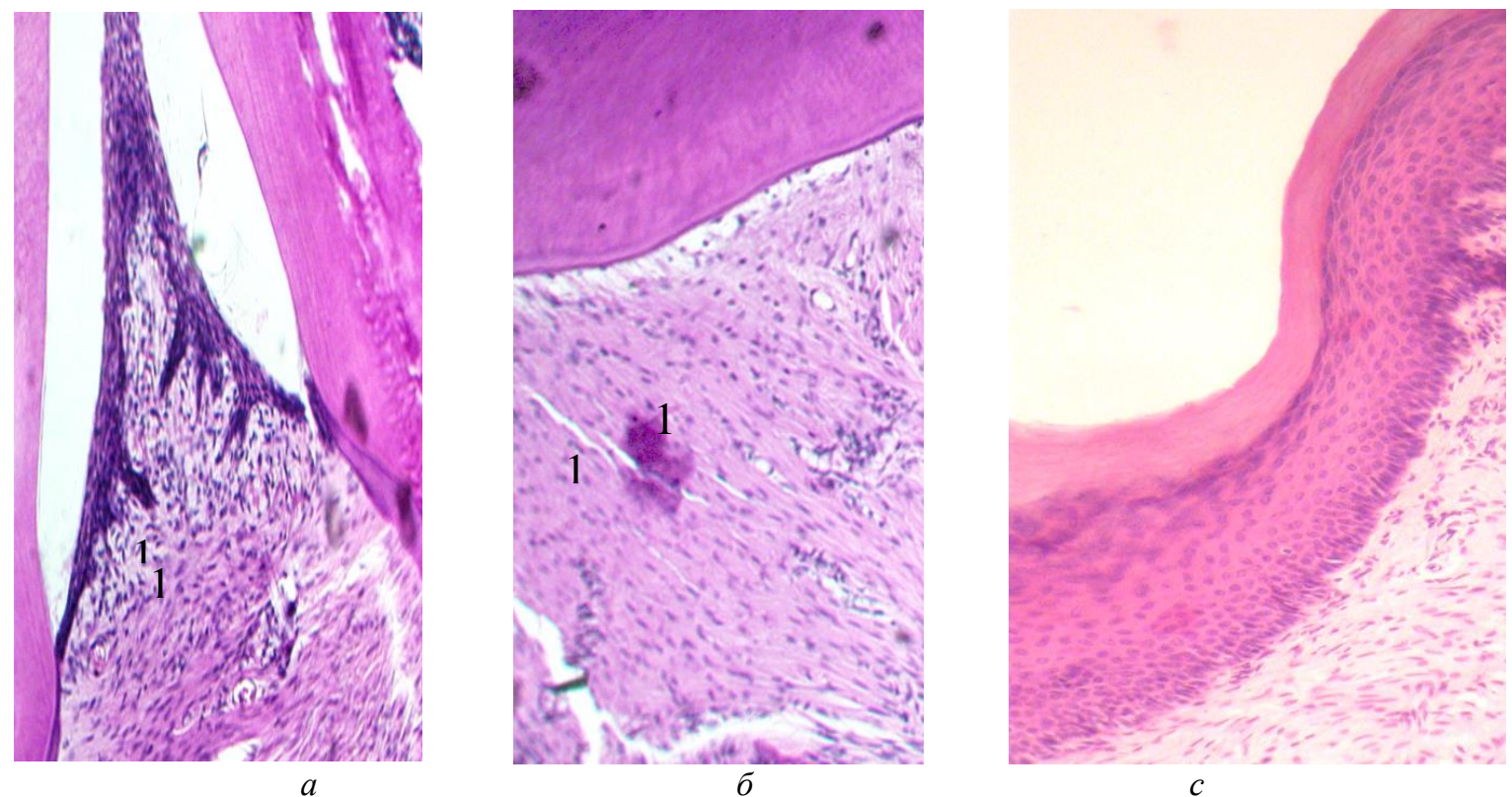

Fig. 4. Periodontium (a, b) and free gums (c) of rats with experimental periodontitis after therapeutic irrigation of the oral cavity with Resibron: $a$ - normal condition of the gingival papilla (1), the epithelium is attached at the level of the enamel-cement border; $b$ - the state of the periodontal ligament is not changed (1); $c$ - loose gingiva without features. Hematoxylin and eosin. $\times 200$

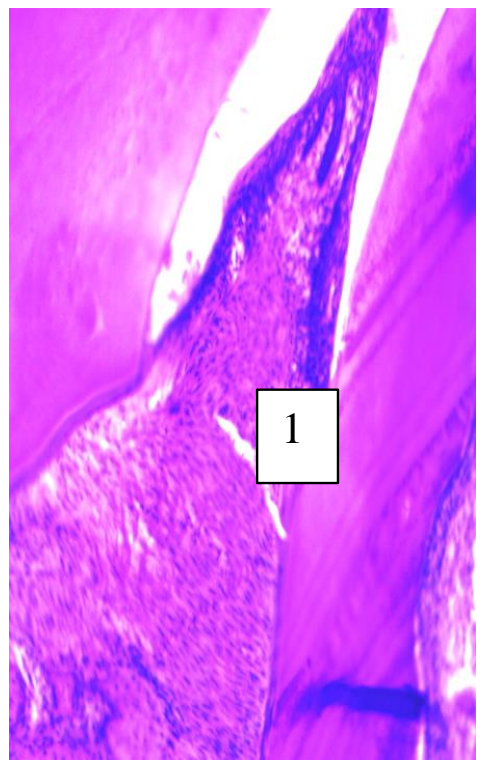

$a$

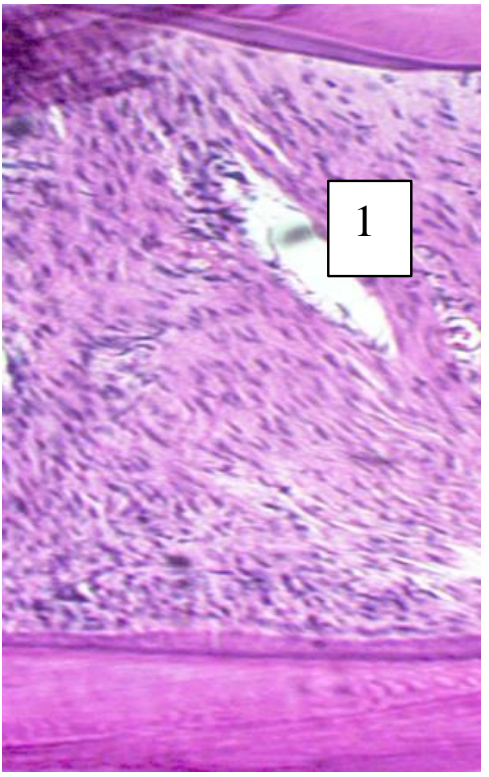

$\sigma$

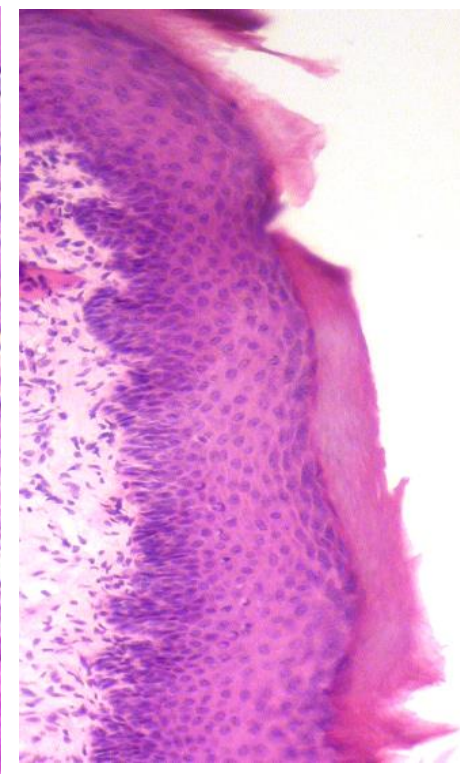

c

Fig. 5. Periodontium (a, b) and free gums (c) of rats with experimental periodontitis after therapeutic irrigation of the oral cavity "Imudon": $a$ - no changes in the state of the interdental gingival papilla (1), the level of epithelial attachment and the enamel-cement border coincide; $b$ - the state of the periodontal ligament (1) is not changed; $c$ - the mucous membrane of the free gums was unremarkable. Hematoxylin and eosin. $\mathrm{a}-\times 100, \mathrm{~b}-\times 250, \mathrm{c}-\times 200$ 


\section{Discussions}

Reproduction of experimental periodontitis according to the above method, as shown by the results obtained, significantly led to a change in the reactivity and resistance of the organism, that is, the histological picture of the pathological experimental process in rats of the control pathology group corresponds to the state of periodontitis of moderate severity with a generalized nature of the lesion, manifestations that affect both soft and hard periodontal tissues $[10,11]$. These results made it possible to use the drug to improve the course of experimental periodontitis with a more crushed antigenic composition "Respibron" and to compare it with the known drug of the classical method of obtaining bacterial antigens "Imudon". It is generally known that inflammation and dysbiosis reinforce each other, since the breakdown products of inflammatory tissue are used by the dysbiotic microbiota as nutrients $[7,12,13]$. The progression of periodontitis is characterized by the formation of periodontal pockets and inflammatory bone loss [14, 15]. Therapeutic tactics aimed at stimulating local and systemic immune responses leads to stable positive dynamics and stable remission $[16,17]$. The degree of response of immunocompetent cells is reflected by morphological changes, as demonstrated by our studies. At the end of the experiment, the magnitude of destruction remained in the control pathology group and differed from the norm by 397 times. The morphometric data of "Imudon" periodontal tissues indicate a significant improvement in the signs characterizing their condition, the magnitude of destruction was 64 times higher than the indicators in relation to the intact control, but in relation to the control pathology decreased by 6.2 times. The dynamics of the studied morphometric indicators against the background of the use of "Respibron" was similar to the dynamics of the indicators of imudon, but the magnitude of destruction was less pronounced and differed at the end of the experiment by 17.2 times in comparison with the intact control, and in the control group the results improved by 23.1 times.

The described complex of positive histological changes under the action of bacterial lysates makes it possible to compare the activity of bacterial lysates, which are antigenically equal, but obtained by different technological methods. "Respibron", administered against the background of pathology in a therapeutic mode, has a pronounced therapeutic effect, prevents bone resorption, the formation of periodontal pockets, an inflammatory reaction in the periodontal ligament and the mucous membrane of the free gums. In terms of the severity of the positive effect on the histological state of the periodontal tissues of rats "Respibron" is ahead of the comparison drug "Imudon". The results obtained will be confirmed or refuted by our studies of immunological parameters, cytokine profile. Such data will make it possible to achieve a more pronounced therapeutic effect and long-term remission in patients with periodontitis.

The scientific novelty lies in the pathophysiological study of the features of the course of morphological changes on an experimental model of periodontitis and pharmacological correction. The practical significance of carrying out a number of pathophysiological studies for medical practice based on the theoretical generalization and new solution of the urgent scientific and practical problem of modern biological and medical pathological physiology - the role of the influence of bacterial lysates in the pathogenetic therapy of periodontitis, which makes it possible to pathogenetically substantiate the principles of correction of this pathological process.

Study limitations. The limitation of the study is the insufficient number of studied morphometric parameters of dental dentin involved in the experiment, for a more accurate statistical calculation of the results obtained in the laboratory, however the tasks were performed.

A prospective study of the cytokine mechanisms of the course of chronic periodontitis of the oral cavity against the background of changes in the parameters of immune relationships will make it possible to find ways of rational therapeutic tactics on the example of the action of the natural microbiota of preparations of bacterial lysates. This will allow analysis of the potential effects of such anti-inflammatory therapy in future studies.

\section{Conclusions}

1. It has been proven that by the end of 90 days of observation of the course of experimental periodontitis, compensatory mechanisms are depleted to a state of decompensation at the local level in the homogenate of animal gum tissue and characterized by the formation of periodontal pockets and inflammatory bone loss. The magnitude of destruction differed from the norm by 397 times.

2 . The powerful corrective effect of bacterial lysates "Respibron" and "Imudon" preparations on morphometric and histological parameters on the model of chronic experimental periodontitis has been reliably established. The dynamics of the studied morphometric indicators against the background of the use of "Respibron" was similar to the dynamics of the indicators of "Imudon", but the magnitude of destruction was less pronounced and differed at the end of the experiment by 17.2 times in comparison with the intact control, and in the control group the results improved by 23.1 times.

3. The therapeutic effect of "Respibron" can be assessed as more powerful in comparison with "Imudon" in terms of the studied morphometric and histological parameters: the magnitude of improvement "Respibron" was 3.72 times higher than the indicators of "Imudon".

The obtained results make it possible to continue the study of the course of experimental periodontitis from the point of view of establishing the mechanisms of development, protection, and restoration of tissues under conditions of pharmacological correction by bacterial lysate "Respibron".

\section{Conflict of interests}

The authors declare that they have no conflicts of interest.

Financing

The study was performed without financial support. 


\section{References}

1. Borisenko, A. V. (2013). Zabolevaniya parodonta. Kyiv: VSI «Meditsina», 456.

2. Ushakov, R. V., Gerasimova, T. P. (2017). Mekhanizmy tkanevoi destruktsii pri parodontite. Stomatologiya, 4, 63-66.

3. Borzikova, N. S. (2015). Markers of inflammation in the periodontal diseases. Medical Council, 2, 78-79.

4. Ponomareva, N. A., Gus'kova, A. A., Mitina, E. N., Grishin, M. I. (2017). Modern methods of treatment of inflammatory diseases of the parodont. Health and Education Millennium, 19 (10), 123-125. doi: http://doi.org/10.26787/nydha-2226-7425-201719-10-123-125

5. Sidelnikova, L. F., Dimitrova, A. G., Kolenko, YU. G. (2018). Otsenka effektivnosti primeneniya immunomodulyatora v kompleksnom lechenii generalizovanogo parodontita. Stomatologiya: ot nauki do praktiki, 1, 86.

6. Darenskaya, M. A., Grebenkina, L. A., Mokrenko, E. V., Suslikova, M. I., Gubina, M. I., Goncharov, I. S. et. al. (2019). Korrektsiya metabolicheskikh narushenii pri vospalitelnykh zabolevaniyakh parodonta u krys s pomoschyu immunomodulyatora. Sovremennye problemy nauki i obrazovaniya, 2. Available at: http://science-education.ru/ru/article/view?id=28742 Last accessed: 06.12.2020

7. Corona, P. S., Lung, M., Rodriguez-Pardo, D., Pigrau, C., Soldado, F., Amat, C., Carrera, L. (2018). Acute periprosthetic joint infection due to Fusobacterium nucleatum in a non-immunocompromised patient. Failure using a Debridement, Antibiotics + Implant retention approach. Anaerobe, 49, 116-120. doi: http://doi.org/10.1016/j.anaerobe.2017.12.010

8. Butenko, H. M., Tereshina, O. P., Maksymov, Yu. M., Arkadiev, V. H et. al.; Stefanova, O. V. (Ed.) (2001). Vyvchennia imunotoksychnoi dii likarskykh zasobiv. Kyiv: Avitsena, 102-114.

9. Kushkun, A. A. (2007). Rukovodstvo po laboratornym metodam diagnostiki. Moscow: «GEOTAR-Media», 800.

10. Colgan, S. P. (2015). Neutrophils and inflammatory resolution in the mucosa. Seminars in Immunology, 27 (3), 177-183. doi: http://doi.org/10.1016/j.smim.2015.03.007

11. Dimitrova, A. G., Kolenko, YU. G. (2017). Otsenka effektivnosti razlichnykh immunomodulyatorov v kompleksnom lechenii generalizovannogo parodontita u lits molodogo vozrasta (18-25 let). Sovremennaya stomatologiya, 2, 38-39.

12. Ortiz-García, Y. M., García-Iglesias, T., Morales-Velazquez, G., Lazalde-Ramos, B. P., Zúñiga-González, G. M., OrtizGarcía, R. G., Zamora-Perez, A. L. (2019). Macrophage Migration Inhibitory Factor Levels in Gingival Crevicular Fluid, Saliva, and Serum of Chronic Periodontitis Patients. BioMed Research International, 2019, 1-7. doi: http://doi.org/10.1155/2019/7850392

13. Pedigo, R. A., Amsterdam, J. T. (2018). Oral medicine. Rosen's emergency medicine: concepts and clinical practice. Chap. 60. 9th ed. Philadelphia: Elsevier. doi: http://doi.org/10.1016/b978-0-323-05472-0.00068-2

14. Dommisch, H., Kebschull, M.; Newman, M. G., Takei, H. H., Klokkevold, P. R., Carranza, F. A. (Eds.) (2015). Chronic periodontitis. Carranza's clinical periodontology. Chap. 23. 12th ed. St Louis: Elsevier Saunders, 313-320.

15. Lutskaya, I. K. (2017). Bolezni parodonta. Moscow: Meditsinskaya literatura, 256.

16. Bose, A., Shetty, S., Ajila, V. (2016). Molecular biology of host microbial interaction in periodontal disease. LAP LAMBERT Academic Publishing, 160.

17. Campbell, E. L., Kao, D. J., Colgan, S. P. (2016). Neutrophils and the inflammatory tissue microenvironment in the mucosa. Immunological Reviews, 273 (1), 112-120. doi: http://doi.org/10.1111/imr.12456

Received date 29.07.2021

Accepted date 26.08.2021

Published date 30.09.2021

Mariia Ievtushenko, Postgraduate Student, Department of Clinical Pathophysiology, Topographic Anatomy and Operative Surgery, Kharkiv Medical Academy of Postgraduate Education, Amosova str., 58, Kharkiv, Ukraine, 61176

Olena Koshova, PhD, Associate Professor, Department of Microbiology, Virology and Immunology, National University of Pharmacy, Pushkinska str., 53, Kharkiv, Ukraine, 61002

Svitlana Kryzhna, Doctor of Medical Sciences, Professor, Department of Cardiology, Laboratory and Functional Diagnostics, V. N. Karazin Kharkiv National University, Svobody sq., 4, Kharkiv, Ukraine, 61022

*Corresponding author: Svitlana Kryzhna, e-mail: kryghna@gmail.com 